\title{
Strategi Pelibatan Generasi Muda Dalam Pengelolaan Pariwisata Di Desa Tenganan Pegringsingan, Kecamatan Manggis, Kabupaten Karangasem
}

Putu Guntur Pramana Putra a, 1, Saptono Nugroho a, 2

1putuguntur66@gmail.com, 22saptono_nugroho@unud.ac.id

a Program Studi S1 Destinasi Pariwisata, Fakultas Pariwisata,Universitas Udayana, Jl. Dr. R. Goris, Denpasar, Bali 80232 Indonesia

\section{Abstract}

The research aims to find out tourism potential and what strategy for involving young generation in managing tourism at the village of Tenganan Pegringsingan. The research was located at the village of Tenganan Pegringsingan. The scope of research was reinterpretation, Think Global and Act Locally, institutionalization, and institutional, type of data being used was qualitative data, source of data being used was primary and secondary data. Data sampling method being used was observation, interview and documentation study. Informant determination in this qualitative study was using Purposive Sampling. Data analysis being used was descriptive qualitative. The first to be done was conducting observation to social phenomenon, and then conducting categorization toward obtained information, next was explaining categorization, and then explaining the relation of categorization and drew general conclusions.

Based on the result obtained, natural potential possessed by the village of Tenganan consists of vast rice fields, suitable to be used as trekking path across rice fields, and green forest which has been managed as ecotourism and existing trekking path. Existing cultural potential among others was, such as "Nyakan Suci, Neduh, Mekare-kare, Muhu-muhu, Mesanggah Gedebong, Mesanggah Bongkot, Munjung, Metruna Nyoman, Maling-malingan" and other traditions. This cultural potential becomes the attraction for tourists to visit the village of Tenganan.

The strategy for involving young generation which including role reinterpretation attempted through internal and external of young generation. Next the slogan of Think Global and Act Locally, through global thinking and acting locally, and institutionalization covering tourism spirit of young generation, spirit to mastering internet in developing tourism network and spirit to carry forward the tradition of the ancestors. Next is institutional which including the strengthening of organization based on culture namely Sekaha Truna and Deha. The extension of Sekeha Truna Truni based on the necessity, based on Tourism Management such as Sekaha Truna and Truni. So, the role of young generation in tourism management is very important for regeneration of tourism management at the village of Tenganan in the future.

Keywords: The younge generation, The involving strategy, Managing tourism, Tenganan Pegringsingan Village

\section{PENDAHULUAN}

Dampak pariwisata yang menonjol dalam kehidupan masyarakat lokal adalah dampak terhadap stratifikasi sosial dan mobilitas sosial, karena pariwisata merupakan salah satu wahana demokratisasi (Cohen, 1984) dalam Pitana (2005). (Greenwood, 1972) dalam Pitana (2005) mengatakan bahwa pariwisata mempunyai dampak yang sangat besar terhadap mobilitas vertikal. Perkembangan ekonomi yang disebabkan oleh pariwisata menyebabkab tumbuhnya kelas-kelas menengah baru, yang senantiasa ada dalam situasi kompetisi dengan kelas menengah yang ada sebelumnya. Tujuan wisata dunia memiliki potensi yang menunjang pertumbuhan kepariwisataan. Potensi tersebut mencakup potensi manusia, alam, maupun kebudayaan. Pulau Bali merupakan pusat pariwisata di
Indonesia. Perpaduan manusia, alam dan kebudayaan Bali yang unik berlandaskan pada konsep Tri Hita Karana yang mewujudkan keharmonisan atau

keseimbangan, keindahan yang ideal dan bermutu tinggi, yang menjadikan Bali sebagai primadona pariwisata Indonesia yang sudah terkenal diseluruh belahan dunia. Pulau Bali memiliki banyak daya tarik wisata yang menarik dengan keindahan alam serta budaya. Kita lihat daerah timur Bali tepatnya di Desa Tenganan Pegringsingan, Kecamatan Manggis, Kabupaten Karangasem yang merupakan desa tua sebagai jejak peradaban Bali Kuno Desa Tenganan merupakan desa dengan alam serta budaya yang sangat unik dan berbeda dengan yang lainnya. 
Desa Tenganan sangat memegang teguh konsep kehidupan yaitu Tri Hita Karana yang mengandung arti keseimbangan atau keharmonisan.

Desa Tenganan sudah terkenal dengan tradisi perang pandan yang telah tersohor sampai ke mancanegara. Hal ini tidak terlepas dari peran generasi muda dalam melestarikan budayanya. Pada saat upacara-upacara keagamaan generasi muda selalu ikut dan selalu terlibat, dikarenakan generasi muda Tenganan yang nantinya akan meneruskan adat serta tradisi leluhur yang masih lestari hingga saat ini.

Namun, keberadaan pariwisata yang di tunjang oleh alam serta budaya, tidak dikelola dengan maksimal oleh generasi muda. Hal ini disebakan karena generasi muda enggan dan blum mau berkecimpung di dunia pariwisata, selain itu generasi muda Tenganan belum paham mengenai pengelolaan pariwisata yang baik dan benar. Disisi lain, sumber daya manusia generasi muda Tenganan dalam hal penguasaan bahasa asing masih kurang, sehingga mereka merasa kurang percaya diri. Hal ini menyebabkan kekhawatiran dari generasi tua. Menurut mereka, lambat laun nantinya tidak ada lagi generasi yang meneruskan pengelolaan pariwisata di Desa Tenganan. Keberadan dan kehadiaran dari generasi muda sangat diharapkan oleh generasi tua, agar nantinya pengelolaan pariwisata di Tenganan akan tetap berlanjut. Maka dari itu kiranya menarik untuk melakukan penelitian ini untuk mengetahui apa penyebab generasi muda enggan untuk mengelola pariwisata dan bagaimana strategi agar generasi muda agar mau terlibat dalam pengelolaan pariwisata di Desa Tenganan Pegringsingan.

\section{TINJAUAN PUSTAKA}

\section{Pariwisata Budaya}

Pengertian Pariwisata Budaya menurut (Geriya 1995:103) dalam Bayu (2012) adalah salah satu pariwisata yang mengandalkan potensi kebudayaan sebagai daya tarik yang paling dominan serta sekaligus memberikan identitas bagi pengembangan pariwisata tersebut. Dalam kegiatan pariwisata terdapat sepuluh elemen budaya yang menjadi daya tarik wisata, yakni : 1). kerajinan, 2) tradisi, 3). sejarah dari suatu tempat/daerah, 4). arsitektur, 5). makanan lokal/tradisional, 6). seni dan musik, 7). cara hidup suatu masyarakat, 8). agama, 9). bahasa, 10). pakaian lokal/tradisional (Shaw dan William, 1997) dalam Bayu (2012).

\section{Konsep Generasi Muda}

Generasi Muda merupakan terjemahan dari young generation, oposisi dari old age. Youth menandun arti populasi remaja/anak muda/pemuda yang sedang berproses membentuk dirinya. Pengertian generasi muda erat hubungannya dengan arti generasi muda sebagai penerus. Ada tiga hal terkait dengan makna "muda", yaitu generasi muda yang dalam hal ini adalah individu yang berumur 0 sampai 30 tahun. Sedang yang dimaksud dengan pemuda adalah individu yang berumur antara 15-30 tahun. Selanjutnya, masa transisi dewasa dikenal dengan genarasi peralihan (transisi), yaitu mereka yang berumur 30-40 tahun. Generasi muda dalam konteks tulisan ini menggunakan batasan tentang pemuda, yaitu mereka berada rentang usia 15-30 tahun.

Dalam konteks pariwisata, jika dimaknai sebagai sebuah ranah yang berarti ruang perjuangan akumulasi modal, posisi generasi muda memiliki makna yang khas. Di satu sisi, jika ditinjau dari konsepsi modal, posisi generasi muda relatif kelompok yang kurang diperhitungkan karena inkompetensinya dalam mengakumulasi modal (sumber daya pariwisata). Meraka kalah saing dengan kelompok lain yang disebut dengan elit pariwisata. Hal ini terkait dengan konsepsi habitus, yang dengannya kapasitas tiap aktor dalam berinteraksi akan terukur. Generasi yang lebih senior dianggap telah matang dan mampu menguasai persoalan, yang jika ditinjau dari konsepsi modal : mereka tidak berkeinginan untuk sharing modal dengan generasi muda. Sikap ini juga berangkat dari stereotype yang menganggap generasi muda belum mampu, belum matang, dan masih emosional dalam mengelola pariwisata. (Nugroho, 2016)

\section{Konsep Strategi Pelibatan Generasi Muda}

Strategi pelibatan generasi muda dalam praktik pengelolaan pariwisata adalah adanya cara pandang kepada generasi muda terhadap 
pengelolaan pariwisata, dapat dilihat dari beberapa aspek :

1) Pelembagaan, dalam strategi ini meliputi beberapa hal yang terkait, yakni sebagai berikut :

a) Massifikasi potensi elan vital (spirit) pariwisata generasi muda

b) Spirit menguasai teknologi berbasis internet dan pemanfaatanya dalam mengembangkan jaringan

c) Sterilisasi kepentingan politik praktis tanpa menjadi apolitis

2) Kelembagaan, dalam strategi ini meliputi beberapa hal yang terkait, yakni sebagai berikut :

a) Penguatan organisasi pemuda berbasis budaya (Sekeha Truna-Truni)

b) Ekstensi Sekeha Truna Truni berbasis kebutuhan berbasis pengelolaan pariwisata

c) Forum komunikasi pemuda dalam pengelolaan pariwisata (Nugroho, 2016)

\section{Konsep Pengelolaan Pariwisata}

Pengelolaan pariwisata haruslah mengacu pada prinsip-prinsip pengelolaan yang menekankan pada nilai-nilai kelestarian lingkungan, komunitas lokal, dan nilainilaisosial daerah tersebut sehingga wisatawan menikmati kegiatan wisatanya serta bermanfaat bagi kesejahteraan masyarakat sekitar daerah pariwisata. Menurut Cox (1985) dalam Pitana, (2009) pengelolaan pariwisata harus memperhatikan prinsip-prinsip sebagai berikut :

a. Pembangunan dan pengembangan pariwisata haruslah didasarkan pada kearifan lokal dan special local sense yang merefleksikan keunikan peninggalan budaya dan keunikan lingkungan.

b. Preservasi, proteksi, dan peningkatan kualitas sumber daya yang menjadi basis pengembangan kawasan pariwisata.

c. Pengembangan atraksi wisata tambahan yang mengakar pada khasanah budaya lokal.

d. Pelayanan kepada wisatawan yang berbasis kepada keunikan budaya dan lingkungan lokal. Memberikan dukungan dan legitimasi pada pembangunan dan pengembangan pariwisata jika terbukti memberikan manfaat positif, tetapi sebaliknya mengendalikan dan/atau menghentikan aktivitas pariwisata tersebut jika melamui ambang batas lingkungan alam atau aksetabilitas sosial walaupun di sisi lain mampu meningkatkan pendapatan masyarakat.

\section{METODE PENELITIAN}

Penelitian ini mengambil lokasi di Desa Tenganan Pegringsingan, Kecamatan Manggis, Kabupaten Karangasem. Berjarak sekitar 65 $\mathrm{Km}$ dari kota Denpasar ke arah timur dengan menempuh waktu sekitar 1 jam 30 menit. Desa Tenganan Pegringsingan dipilih menjadi lokasi penelitian ini dikarenakan beberapa alasan yaitu Desa Tenganan Pegringsingan memiliki potensi alam, manusia serta budaya yang unik dikenal sampai mancanegara dan lebih terpenting adalah sejauh mana keterlibatan generasi muda Tenganan Pegringsingan dalam ikut mengelola pariwisata di desanya.

Ruang Lingkup Penelitian adalah untuk membatasi penelitian dan mempertegas aspek data yang meliputi : reinterprestai peran, think local and locally, pelembagaan ( Spirit pariwisata generasi muda, spirit menguasai teknologi, spirit meneruskan tradisi leluhur), dan kelembagaan (penguatan organisasi budaya dan organisasi/sekaha berbasis pengelolaan pariwisata).

Jenis data dalam penelitian ini adalah data kualitatif. Dalam penelitian ini, data kualitatif yang dimaksud adalah data yang berupa gambaran umum Desa Tenganan Pegringsingan, potensi yang dimiliki oleh Desa Tenganan Pegringsingan, pelembagaan dan kelembagaan, maupun posisi generasi muda dalam ranah pariwisata di Desa Tenganan Pegringsingan.

Sumber data yang digunakan dalam penelitian ini adalah data primer dan data sekunder. Data Primer yang dimaksud dalam penelitian ini adalah wawancara dengan pihak yang terkait yakni Tokoh masyarakat Desa Tenganan Pegringsingan, elit desa, tokoh pemuda, dan beberapa masyarakat yang terlibat dalam pengelolaan pariwisata di Desa Tenganan Pegringsingan. Data Sekunder yang dimaksud adalah data kunjungan wisatawan, serta data pelembagaan dan kelembagaan di Desa Tenganan Pegringsingan.

Metode pengumpulan data yang dilakukan adalah observasi, wawancara dan 
studi dokumentasi. Observasi dilakukan untuk mengetahui kondisi dan keadaan langsung dilapangan. Wawancara dilakukan dengan tokoh masyarakat, elit desa, tokoh pemuda, dan masyarakat untuk melengkapi hasil serta menguatkan hasil temuan di lapangan. Studi dokumentasi digunakan untuk melengkapi dan mendukung hasil di lapangan yang berupa data profil Desa Tenganan.

Penentuan Informan dalam penelitian kualitatif ini memakai Purposif Sampling yaitu menentukan kelompok peserta yang menjadi informan sesuai dengan kreteria terpilih yang relevan dengan masalah penelitian tertentu. Dalam penelitian ini yang dimaksud adalah tokoh masyarakat, generasi muda, dan generasi tua.

Teknik analisa data yang digunakan dalam laporan penelitian ini adalah teknik analisis data kualitatif. Teknik analisis data kualitatif merupakan proses mencari dan menysun secara sisematis data yang diperoleh dari hasil wawancara, catatan lapangan, dan dokumentasi, dengan cara mengorganisasikan data dalam kategori, menjabarkan ke dalam unit-unit, melakukan sintesa, menyusun ke dalam pola, memilih mana yang penting dan yang akan dipelajari, dan membuat kesimpulan sehingga mudah dipahami oleh diri sendiri maupun orang lain. (Sugiyono, 2014). Dari paparan diatas, adapun informasi yang didapat dilapangan yaitu menggambarkan dengan jelas gambaran umum Desa Tenganan, mengetahui potensi Desa Tenganan, serta strategi pelibatan generasi muda dalam pengelolaan pariwisata di Desa Tenganan Pegringsingan.

\section{HASIL DAN PEMBAHASAN}

\subsection{Kondisi Geografis}

Berdasarkan Profil Desa Tenganan Tahun 2010, bahwa Desa Tenganan Pegringsingan terletak di Kecamatan Manggis, Kabupaten Karangasem. Sekitar 1,5 jam ke timur dari Kota Denpasar. Menurut data monografi Desa Tenganan Pegringsingan jumlah penduduk sebanyak 1.044 orang dengan jumlah KK 338 KK, yang terbagi menjadi lakilaki sejumlah 530 orang dan Perempuan sejumlah 514 orang. Desa Tenganan memiliki luas wilayah 1.176,225 Ha. Dengan luas wilayah tersebut, Desa Tenganan Pegringsingan memiliki batas wilayah desa. Adapun batas wilayah desa tersebut adalah sebagai berikut : Sebelah Utara berbatasan dengan Desa Bebandem, Kecamatan Bebandem. Sebelah Timur berbatasan dengan Desa Asak, Kecamatan Karangasem. Sebelah Selatan berbatasan dengan Desa Pesedahan, Kecamatan Manggis. Sebelah Barat berbatasan dengan Desa Ngis, Kecamatan Manggis.

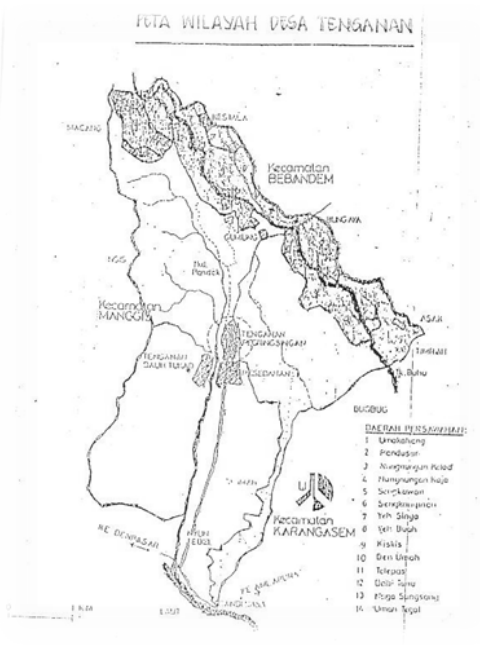

Gambar 4.1 Peta Wilyah Desa Tenganan Pegringsingan.

Sumber : Peta Tenganan Pegringsingan. Profil Desa Tenganan Pegringsingan Tahun 2010.

\subsection{Potensi Desa Tenganan Pegringsingan}

\section{Potensi Alam}

Desa Tenganan memiliki letak geografis yang sangat cocok sebagai daerah bercocok tanam/pertanian. Desa Tenganan memiliki luas wilayah 1.176,225 Ha. Potensi alam yang memadai yakni luas tanah daratan yang cukup luas untuk menghasilkan suatu produksi pertanian pada khusunya. Luas lahan persawahan Tenganan sekitar 225,845 Ha. Dengan luas lahan pesawahan tersebut dapat dimanfaatkan sebagai wisata alam yang menarik bagi wisatawan untuk mengelilingi melintasi indahnya persawahan. Selian persawahan, Tenganan juga memiliki potensi hutan yang masih terjaga kehijuannya sampai saat ini. Dengan luas wilayah hutan sekitar 197,321 Ha yang seluruhnya dimiiki oleh Adat. Pemanfaatkan hutan sudah sejak lama dikelola untuk kegiatan ekowisata Tenganan, yakni pemanfaatan untuk jalur trecking. Trecking merupakan bentuk perjalan wisata yang dilakukan dengan berjalan kaki menyusuri 
suatu kawasan yang memiliki karakteristik khas tertentu, dalam hal ini menyusuri lebatanya hutan Tenganan.

\section{Potensi Budaya}

Desa Tenganan sebagai jejak peradaban Bali Kuno merupakan salah satu desa yang berpenduduk orang Bali Aga (Bali Asli). Bali Aga mengandung arti Bali yang orangnya memang benar-benar orang asli Bali. Pada prinsipnya masyarakat desa Tenganan memegang teguh konsep kehidupannya yaitu Tri Hita Karana yang berarti hubungan harmonis atau keseimbangan. Dilihat dari potensi budaya, adat-istiadat maupun upacara, masyarakat Tenganan memang berbeda dengan masyarakat Bali pada umumnya. Salah satu contoh kegiatan kemasyarakatan yang masih sangat kental mengusung nilai Bali Aga adalah kegiatan-kegiatan yang dilakukan setiap bulannya. Tenganan memiliki tradisi-tradisi yang unik seperti : "Nyakan Suci" ritual memasak di depan Pura Bale Agung dengan menggunakan kayu bakar dari pohon cempaka, "Neduh" ritual sabung ayam atau peyembelihan ayam oleh krama desa, "Mekare-kare" yang sering disebut dengan perang pandan merupakan ritual perang bersenjatakan pandan berduri dan tameng ata, "Mesanggah Jumu" ritual menaruh kotak yang diisi bunga di depan pintu masuk rumah, "Muhu-Muhu" ritual pemotongan banteng jantan, "Mesanggah Gedebong" ritual setiap keluarga membuat sesaji dari batang pisang berhiaskan janur yang diletakkan di depan tempat acara yang dipimpin oleh pemuda/pemudi disetiap keluarga, serta ritual-ritual lain seperti "Mesanggah Bongkot, Munjung, Metruna Nyoman, Maling-Maling" dan lainnya. Potensi keanekaragaman budaya, tradisi dan pola hidup masyarakat Tenganan serta bentuk bangunan yang masih tradisonal menjadi magnet penarik bagi wisatawan untuk berkunjung, baik wisatawan domestik maupun macanegara.

\subsection{Strategi Pelibatan Generasi Muda}

Strategi pelibatan generasi muda dalam pariwisata adalah adanya cara pandang kepada generasi muda terhadap pengelolaan pariwisata yang ada di daerahnya, dapat dilihat dari beberapa aspek sebagai berikut :

\section{Reinterpretasi Peran}

Reinterpretasi peran merupakan penafsiran kembali (ulang) tentang peran generasi muda dalam pariwisata. Proses, cara, menafsirkan kembali terhadap peran generasi muda dalam pengelolaan pariwisata. Reinterprestasi peran terhadap generasi muda adalah peran serta rasa kepedulian yang kurang dari generasi muda menyebabkan kekhawatiran generasi tua menganai masa depan pariwisata Tenganan. Generasi tua tidak ingin pariwisata Tenganan yang sudah dikenal banyak orang nantinya akan lambat laun akan menurun dan akhirnya justru pariwisata Tenganan akan mati" karena tidak ada lagi generasi yang melanjutkannya. Adapun upaya yang dilakukan untuk menumbuhkan dan meningkatkan rasa kepedulian yang kurang oleh generasi muda Tenganan terhadap keberadaan pariwisata di desanya adalah sebagai berikut :

a. Internal Generasi Muda

Meningkatkan SDM pariwisata melalui pelatihan-pelatihan berbahasa asing yang nantinya siap untuk menjadi pemandu wisata. Mengajak generasi muda lainnya untuk terlibat dalam pengelolaan pariwisata. Meghapuskan rasa kurang percaya diri generasi muda dan menumbuhkan rasa percaya diri bahwa meraka juga mampu mengelola pariwisata serta menunjukkan bahwa meraka juga pantas untuk meneruskan tradisi budaya sebagai daya tarik utama pariwisata Tenganan. Selain itu, generasi muda harus menyiapkan diri untuk menghadapi menghadapi dampak positif dan negatif dari pariwisata serta cara penanggulangannya.

b. Eksternal Generasi Muda

Menghapuskan rasa kekhawatiran dari generasi tua, yang khawatir terhadap masa depan pariwisata Tenganan dengan cara melibatkan diri dalam pengelolaan pariwisata. Membangun dan meningkatkan komunikasi antara genarasi tua dan dan generasi muda, agar tidak ada " $g a p$ " atau kesenjangan diantara mereka.

\section{Think Globally, Act Locally}

Generasi muda Tenganan harus mampu "think globally, act locally", tujuannya adalah generasi muda mampu berwawasan luas dan berpikiran cerdas serta bertindak secara lokal. Dengan memanfaatkan kecanggihan teknologi, generasi muda harus mampu berpikir luas dan cerdas untuk mempromosikan pariwisata di 
desanya, namun tetap bertindak secara lokal, guna meneruskan tradisi dan budayanya sebagai penunjang pariwisata di desanya.

\section{Pelembagaan}

Pelembagaan merupakan suatu proses, usaha serta dorongan untuk nilai-nilai dan aturan-aturan yang baru agar menjadi bagian dari salah satu lembaga. Setelah dikenal, diakui, dan dihargai oleh masyarakat, nilai dan aturan yang baru itu akan ditaati masyarakat dalam kehidupan sehari-hari dan diserap oleh masyarakat.

a. Spirit Pariwisata Generasi Muda

Spirit merupakan kekuatan atau dorongan untuk melakukan sesuatu yang akan dilakukan dengan penuh kesungguhan dengan semangat yang luar biasa. Spirit Pariwisata generasi muda Tenganan dahulu mengenai pengelolaan pariwisata kurang diminati. Namun, spirit pariwisata generasi muda mulai bertumbuh semenjak pihak Desa Adat memperbaiki sarana dan prasarasa pariwisata. Saat ini justru generasi muda sangat setuju dan antusias ingin mengelola pariwisata, karena sudah mulai dilibatkan serta mendapatkan dukungan dari pihak Desa Adat. Keterlibatan Desa Adat serta generasi tua sangat penting karena akan mendorong generasi muda untuk mau bertindak mengelola pariwisata di desanya. Spirit inilah yang menjadi modal untuk meneruskan generasi dalam pengelolaan pariwisata di Desa Tenganan Pegringsingan.

b. Spirit Menguasai Teknologi Berbasis Internet dan Pemanfaatannya Dalam Mengembangkan Jaringan (Pariwisata)

Dalam mempromosikan pariwisata maupun kegiatan adatnya, generasi muda Tenganan sudah memanfaatkan media sosial sebagai media penyampain informasi seperti facebook yang berisikan mengenai rangkain kegiatan adat maupun penyampain informasi lainnya. Setelah melakukan kerjasama dengan Desa Adat dalam peningkatan pengelolaan pariwisata, mereka ingin lebih meningkatkan teknologi penyampain informasi seperti pembuatan website resmi maupun promosi melalui media brosur dan yang lainnya.

c. Spirit Meneruskan Tradisi Leluhur Generasi Muda

Tenganan memiliki banyak tradisi yang unik dan telah diwariskan secara turuntemurun oleh leluhur sampai sekarang. Salah satu tradisi yang sangat terkenal dan merupakan tradisi yang ditunggu-tunggu oleh banyak kalangan adalah tradisi perang pandan atau orang Tenganan disebut dengan "mekarekare". Mekare-kare merupakan tradisi yang sudah ada sejak lama dan masih terjagada sampai saat ini. Tradisi ini sangat berkaitan dengan sejarah terdahulu mengenai keberadaan orang Tenganan. Perang pandan disimboliskan sebagai prajurit perang terdahulu yang gagah berani dalam berperang menghadapi musuh. Tradisi perang pandan ini dilaksanakan setiap tahun pada sasih kalima dalam penanggalan Tenganan sekitar bulan juni. Dengan tradisi yang dimiliki oleh Desa Tenganan, apalagi keberadaan pariwisata sudah dikenal oleh

banyak kalangan, maka generasi muda sangat berantusias untuk melestarikan tradisi ini. Menurut mereka sebagai generasi muda harus tau dan wajib menjalankan tradisi yang sudah ada sejak lama dan bertahan hingga saat ini. Spirit generasi muda seperti inilah yang mampu melestarikan tradisi leluhur serta lebih menjaga keasliannya.

\section{Kelembagaan}

Kelembagaan merupakan wadah untuk generasi muda pada khusunya untuk beroganisasi melatih diri berani memecahkan permasalahan dan merupakan proses pendewasaan. Keberadaan Organisasi sangat efektif sebagai strategi untuk mengajak dan melibatkan generasi muda ikut berkecimpung dan belajar industri pariwisata sebagai sumber pengalaman dan pengahasilan. Adapun organisasi-organisasi yang mampu mendukung dan mengajak generasi muda untuk sadar dengan keberadaan pariwisata dan budayanya adalah sebagai berikut,

a. Penguatan Organisasi Pemuda Berbasis Budaya 1. Sekaha Truna

Sekaha Truna adalah kelompok atau perkumpulan remaja laki-laki yang belum berumah tangga atau belum terikat pernikahan. Organisasi Truna ini mendidik anggotanya dari kecil agar hidup mandiri, bisa bekerja sendiri, dan bisa "menyama braya" yang nantinya mempersiapkan diri untuk kejenjang yang lebih tinggi seperti jenjang pernikahan atau hidup berumah tangga. Disisi lain, meraka juga diajarkan budaya maupun adat-istiadatnya 
sendiri yang harus tetap eksistensi di tengah arus globalisasi saat ini.

2. Deha

Deha yang berarti remaja perempuan yang belum menikah atau belum berumah tangga. Deha adalah perkumpulan remaja perempuan yang belum menikah dan merupakan organisasi adat yang sama kaitannnya dengan Sekaha Truna. Organisasi ini hampir sama dengan Sekaha Truna, namun yang membedakannya adalah hanya keanggotaannya. Organisasi Deha ini juga sama fungsinya seperti Sekaha Truna yang dimana mendidik anggotanya dari kecil agar hidup mandiri, bisa bekerja sendiri, dan bisa "menyama braya" maupun mengajarkan kebudayaan serta adat-istiadatnya.

b. Ekstensi Sekeha Truna Truni Berbasis Kebutuhan, Berbasis Pengelolaan Pariwisata.

\section{Sekaha Truna-Truni}

Sekaha Truna-Truni merupakan organisasi modern yang dimana anggota dari Sekaha Truna-Truni tersebut adalah terdiri dari laki-laki dan perempuan. Organisasi Sekaha Truna-Truni (STT) di Tenganan bernama Sekaha Truna-Truni Yowana Purba Jaya Sakti, dalam artian kata "Yowana" artinya pemuda atau remaja, "Purba" artinya Kuna Dresta "Jaya" artinya kemenangan dan "Sakti" artinya kedigjayaan, jadi Yowana Purba Jaya Sakti artinya Remaja Desa Tenganan harus tetap mempertahankan adat budaya yang adi luhung serta menjaga wilayah yang utuh sehingga mencapai tentram Kertaraharja atau "Purba Jaya Sakti". Dengan beranggotakan sekitar 60 orang, diketuai oleh I Gede Mahendra.

Desa Adat sudah mulai melibatkan generasi muda dalam pengelolaan pariwisata dengan membentuk STT. Yowana Purba Jaya Sakti ini yang bertujuan untuk meningkatkan pengelolaan pariwisata dengan melibatkan generasi muda sebagai pengelolanya. Momentum ini sebagai titik terang untuk generasi muda yang harus peka terhadap keberadaan pariwisata di desanya, apalagi sudah di dukung oleh Desa Adat dan sudah ada payung hukumnya. Hal ini juga berdampak pada generasi muda yang belum memiliki pekerjaan yang bisa direkrut sebagai pengelola, kemudian juga tentunya meningkatkan taraf perekonomian khususya bagi generasi muda untuk belajar memanfaatkan potensi dan peluang yang sudah ada.

\section{SIMPULAN DAN SARAN}

\section{Simpulan}

Potensi yang dimiliki oleh Desa Tenganan Pegringsingan terdiri dari potensi alam dan budaya. Potensi alam yang meliputi persawahan yang luas kemudian hutan hijau yang dijadikan wilayah ekowisata sebagai jalur trecking di Tenganan. Potensi Budaya yang meliputi ragam budaya serta tradisi yaitu : "Nyakan Suci, Neduh,

Mekare-kare, Muhu-Muhu, Mesanggah Gedebong, Mesanggah Bongkot, Munjung, Metruna Nyoman, Maling-malingan" serta tradisi lainnya, sehingga menjadi magnet yang menarik wisatawan untuk berkunjung. Potensi pariwisata yang dimiliki oleh Desa Tenganan Pegringsingan tentunya harus adanya regenerasi untuk mengelolanya, adapun strategi pelibatan generasi muda dalam pengelolaan pariwisata di desanya yaitu : Reinterpretasi peran adalah penafsiran kembali mengenai peran generasi muda dalam pariwisata yang sangat penting dalam melanjutkan kegiatan pariwisata di desanya, Think Globally and Act Locally merupakan berpikir secara global dan bertindak secara lokal, Pelembagaan merupakan suatu proses, usaha serta dorongan untuk nilai-nilai dan aturan-aturan yang baru agar menjadi bagian dari salah satu lembaga, Kelembagaan merupakan wadah untuk generasi muda pada khusunya untuk beroganisasi melatih diri berani memecahkan permasalahan dan merupakan proses pendewasaan.

\section{Saran}

Maka dari itu peran generasi tua sebagai media perantara, yakni agar generasi muda mau ikut terlibat. Dari generasi tua juga harus mampu memberikan solusi mengenai kendalakendala yang dihadapi oleh generasi muda, mulai dari meningkatkan rasa percaya diri generasi muda maupun peningkatan SDM pariwisata. Apabila hal itu sudah dilakukan, maka rasa khawatir dari generasi tua terhadap generasi muda akan terhapuskan. Begitu juga perlunya proses pengontrolan/controlling dari generasi tua kepada generasi muda, guna agar mudah mengawasi dalam praktik pariwisata. 


\section{DAFTAR PUSTAKA :}

Arida, I Nyoman Sukma. 2009. Meretas Jalan Ekowisata Bali.Ekowisata Tenganan. Denpasar. Udayana University Press.

Bungin, burham. 2007. Penelitian Kualitatif : Komunikasi, Ekonomi, Kebijakan publik, dan Ilmu Sosial lainnya. Prenada Media Group

Mahendradata, Universitas. 2016. Desa Tenganan : Eksistensi

Peradaban Bali Mula Di Timur Pulau Seribu Pura. Universitas Mahendradata

Nugroho, Saptono dkk. 2016. Generasi Muda dalam Praktik Desa Wisata di Kabupaten Badung.Bogor. Herya Media

Pariwisata, Destinasi. 2016. Perkembangan dan Pengembangan Desa Wisata. Herya Media

Pitana, I Gde dkk. 2005. Sosiologi pariwisata. Yogyakarta. Andi Offset

Pitana, I Gede dkk. 2009. Pengantar Ilmu Pariwisata. Yogyakarta. Andi Offset

Sugiyono. 2014. Metode Penelitian Kuantitatif Kualitatif Dan $R \& D$. Bandung. Alfabeta

Sumber Lain

Bayu, Made. 2012. Pariwisata Budaya. http://madebayu.blogspot.co.id/search/label/Pariwisata

\%20Budaya, 13 Januari 2017

Profil Desa Tenganan tahun 2010 